\title{
Effects of Heat Treatment on the Characteristics of Royal Paulownia (Paulownia tomentosa (Thunb.) Steud.) Wood Grown in Korea ${ }^{1}$ (iㅛ
}

\author{
Yun Ki, Kim² ${ }^{2}$ Gu Joong $\mathrm{KwOn}^{2} \cdot \mathrm{Ah} \mathrm{Ran} \mathrm{Kim}^{2} \cdot$ Hee Soo Lee ${ }^{2}$. \\ Byantaradarsan Purusatama ${ }^{2} \cdot$ Seung Hwan Lee $^{2} \cdot$ Chun Won Kang $^{3} \cdot$ Nam Hun Kim(D) ${ }^{2, \dagger}$
}

\begin{abstract}
Effects of heat treatment on the characteristics of Royal paulownia (Paulownia tometosa) wood were investigated. The results were compared with those of Suwon silver poplar (Populus tementiglandulosa) and Korean red pine (Pinus densiflora) woods. The wood samples of the three species were treated at $160^{\circ} \mathrm{C}, 180^{\circ} \mathrm{C}, 200^{\circ} \mathrm{C}$ and $220^{\circ} \mathrm{C}$ in an electric furnace for 2 hours. The changes of color, density, mass loss, and relative crystallinity were investigated before and after heat treatment. The lightness $\left(\mathrm{L}^{*}\right)$ decreased rapidly from $200^{\circ} \mathrm{C}$ in all species. There were no change in red-green chromaticity $\left(\mathrm{a}^{*}\right)$ and yellow-blue chromaticity $\left(\mathrm{b}^{*}\right)$ of Royal paulownia and poplar woods with increasing temperature. Whereas, yellow-blue chromaticity $\left(b^{*}\right)$ of Korean red pine wood decreased sharply from $200^{\circ} \mathrm{C}$. Royal paulownia wood showed appreciable color change $\left(\Delta \mathrm{E}^{*}\right)$ after heat treatment above $180^{\circ} \mathrm{C}$. Poplar and pine woods, however, presented significant color change from $160^{\circ} \mathrm{C}$. Color change of the three wood species increased rapidly with increasing temperature. Mass loss of the three wood species by heat treatment was the highest in the Royal paulownia wood and the lowest in the pine wood. Mass loss and relative crystallinity increased and density decreased slightly with increasing temperature. Consequently, it is revealed that Royal paulownia wood showed considerable differences in the temperature of color change, weight loss and change of relative crystallinity compared to the other wood species.
\end{abstract}

Keywords: color change, heat-treated wood, mass loss, Paulownia wood, relative crystallinity

\section{INTRODUCTION}

Currently, over $83 \%$ of the wood consumption in South Korea rely on imported woods. Considering the country's target, domestically grown woods production ratio will $50 \%$ by 2050 , the research on afforestation of economic and fast-growing tree species and the expansion of the usage plans is important.

Along with Korean red pine, Paulownia coreana is an important wood resource that is suitable for Korean cultural backgrounds. As a fastest-growing tree among domestically grown trees, it offers excellent dimensional

\footnotetext{
${ }^{1}$ Date Received August 8, 2018, Date Accepted September 5, 2018

2 Department of College of Forest and Environmental Sciences, Kangwon National University, Chuncheon 24341, Republic of Korea

${ }^{3}$ Department of Housing Environmental Design, Chonbuk National University, Jeonju 54896, Republic of Korea

† Corresponding author: Nam Hun Kim (e-mail: kimnh@kangwon.ac.kr, ORCID: 0000-0002-4416-0554)
} 
Yun Ki, Kim • Gu Joong Kwon • Ah Ran Kim • Hee Soo Lee • Byantaradarsan Purusatama • Seung Hwan Lee $\cdot$ Chun Won Kang $\cdot$ Nam Hun Kim

stability and durability so that it has traditionally been used for making instruments and furniture and other domestic goods. Thus, it is considered relatively high value-added tree species. Growing in Korea, Japan, China and Southeast Asia, Paulownia coreana is from $15 \mathrm{~m}$ to $20 \mathrm{~m}$ tall, and its diameter is up to $80 \mathrm{~cm}$ wide. It grows to be used as woods within ten years after the planting, and it is light and soft so that it can be easily processed. Among the domestically grown Paulownia coreana species, Paulownia coreana UYEKI and Royal Paulownia (Paulownia tometosa (Thunb.) Steud.) have high value of use. As fast-growing tree species, these offer relatively superior wood quality so that their usage can be varied, including biomass resources (Kim, 1997; Kuroiwa, 2010).

There have been studies mainly on the physical properties of domestically grown Royal Paulownia woods (Hong, 1985; Yoo and Jung, 1997; Lee et al., 2008), and recent studies have examined and reviewed the anatomical, physical, dynamic and carbonization properties of the tree trunk, branches, and roots of Royal paulownia woods to evaluate its wood quality and the use as biomass resources.

Heat treatment on wood has been widely used to improve the absorptiveness, dimensional stability, weatherproof performance and discoloring performance (Kim, 2016). Various studies have also been conducted on the heat-treated woods grown in Korea (Cho et al., 2015; Kang et al., 2015; Kim et al., 2009, 2010; Lim et al., 2014; Park et al., 2012; Hidayat et al., 2017a, 2017b; Yoon et al., 2008, 2009). However, there are few studies that applied such heat treatments to useful Korean woods resources, such as Royal paulownia wood. Kang et al. (2015) performed oil-heat treatment on the larch and Paulownia coreana at $200^{\circ} \mathrm{C}$ and observed the surface color change. They reported that the latter had a relatively lower colour change than the former. Hidayat et al. (2017b) compared the color change by the heat treatment of Royal paulownia and determined a heat treatment method and temperature that offer aesthetically pleasing results through a survey. Moreover, Hidayat et al. (2017a) reported that the heat treatment of Royal paulownia wood by fixing it with clamps resulted in the woods that had a smaller decrease in the physical and dynamic properties of the woods. Therefore, it is determined that in the quality evaluation of heat-treated woods, the heat transfer media (air or nitrogen, etc.) by tree species based on the aesthetically pleasing results, and the color change based on the heat treatment temperature and duration are the most important indexes, at which the analysis on the weight change or cellulose crystallization that affect the dynamic properties of woods are also considered important data.

To offer key basic data for the expansion of the usage plan of Royal paulownia woods that have superior added value among tree species grown in Korea, the study examined the color, weight, and density changes as well as the relative crystallinity of cellulose caused by the heat treatment. Furthermore, the study compared and examined the heat treatment properties of Korean red pin wood, a representative Korean tree species as a needleleaf tree wood as well as Suwon silver poplar, one of the broadleaf fast-growing woods.

\section{MATERIALS and METHODS}

\subsection{Specimens}

The study used three specimens of 11 to 15 years old Royal paulownia (Paulownia tomentosa (Thunb.) Steud.) with the diameter about $30 \mathrm{~cm}$ from the experiment forest at Kangwon National University. For a comparison, some 25 years old Suwon silver poplar (Suwon silver poplar, Populus tementiglandulosa T. Lee) in $35 \mathrm{~cm}$ in diameter, acquired from Gunaerim, Kangwon National University, and some 50 years old 
Effects of Heat Treatment on the Characteristics of Royal Paulownia (Paulownia tomentosa (Thunb.) Steud.) Wood Grown in Korea

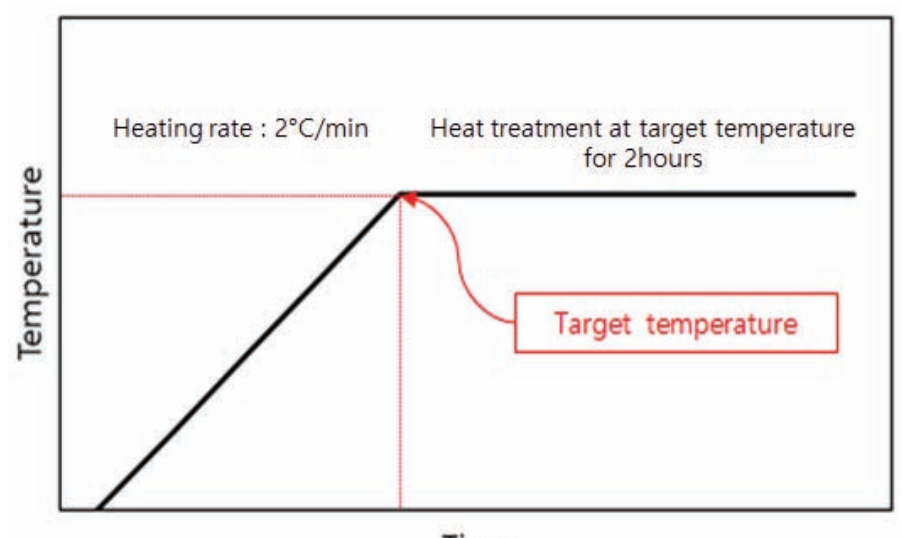

Time

Fig. 1. Schedule for heat treatment.

Korean red pine (Pinus densiflora Siebold \& Zucc.) in some $40 \mathrm{~cm}$ in diameter, acquired from Samcheok, Korea Forest Research Institute were used as specimens.

\subsection{Test method}

\subsubsection{Heat treatment}

Oven-dried specimens of the woods were heat treated for two hours at $160^{\circ} \mathrm{C}, 180^{\circ} \mathrm{C}, 200^{\circ} \mathrm{C}$ and $220^{\circ} \mathrm{C}$, raising the temperature by $2^{\circ} \mathrm{C} / \mathrm{min}$ (Fig. 1). To produce the specimens used in the test and the heat treatment schedule, the study referred to the results from previous studies that showed small distortion or cleavage during the heat treatment process and offered excellent dimensional stability and durability (Hidayat et. al., 2017a).

\subsubsection{Measurement of the color change}

The color change of three tree species by heat treatment was measured with a color-difference meter (NR110, 3nh, China). The specimens for the color change measurement were made in $50 \mathrm{~mm}(\mathrm{~T}) \times$ $20 \mathrm{~mm}(\mathrm{R}) \times 160 \mathrm{~mm}(\mathrm{~L})$ and were treated by heat. The three points of the specimens were measured for color changes (Fig. 2), and the expression of the color change values was based on the CIE-L ${ }^{*} \mathrm{a}^{*} \mathrm{~b}^{*}$ color space measurement by Commission Internationale de I'Eclairage (Han and Cho, 2005). L* shows the difference in lightness, where as $a^{*}$ and $b^{*}$ signify the direction of the color. $-\mathrm{a}^{*}$ is green, $+\mathrm{a}^{*}$ is red, $-b^{*}$ is blue, and $+b^{*}$ is yellow. Based on the measured $\mathrm{L}^{*}, \mathrm{a}^{*}, \mathrm{~b}^{*}$ values, the actual color change $\left(\triangle \mathrm{E}^{*}\right)$ was determined by the equation below, and the color change difference was determined by the color difference proposed by National Bureau of Standards in the US.

$$
\left.\Delta E^{*}=\left(\sqrt{\left(\triangle L^{*}\right)^{2}+\left(\triangle a^{*}\right)^{2}+\left(\triangle b^{*}\right.}\right)^{2}\right)
$$

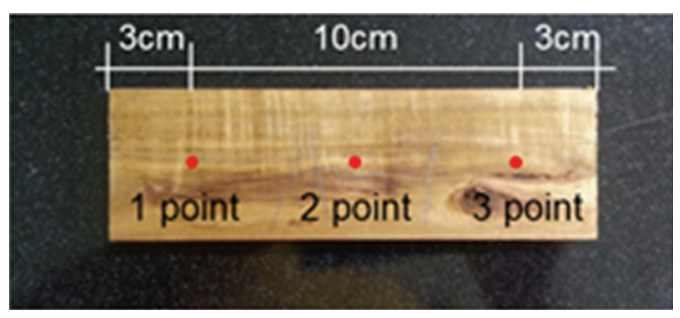

Fig. 2. Measuring point for color change on the surface of wood specimen. 
Yun Ki, Kim • Gu Joong Kwon • Ah Ran Kim • Hee Soo Lee $\cdot$ Byantaradarsan Purusatama Seung Hwan Lee $\cdot$ Chun Won Kang $\cdot$ Nam Hun Kim

\subsubsection{Measurement of density change and weight reduction}

The study measured density chance and weight reduction in the three specimens $(20 \mathrm{~mm}(\mathrm{R}) \times 20 \mathrm{~mm}$ $(\mathrm{T}) \times 40 \mathrm{~mm}(\mathrm{~L})$ by the temperature of heat treatment. The following equation was used to determine the density change and weight reduction based on the oven-dry condition, showing the average value of ten specimens.

$$
\operatorname{Density}\left(\mathrm{g} / \mathrm{cm}^{3}\right)=\frac{M}{V}
$$

V: Oven-dry volume of specimen $\left(\mathrm{cm}^{3}\right)$

M: Oven-dry weight of specimen (g)

$$
\text { weightreduction }(\%)=\left(M_{1}-M_{2}\right) / M_{1} \times 100
$$

$\mathrm{M}_{1}$ : Specimen weight before heat treatment (g)

$\mathrm{M}_{2}$ : Specimen weight after heat treatment (g)

\subsubsection{Analysis of relative crystallinity of cellulose}

Using an X-ray diffractometer (D-Max 2100V, Rigaku, Japan), the study analyzed the relative crystallinity of non-treated and treated wood cellulose.
Specimens in $1 \mathrm{~mm}(\mathrm{R}) \times 10 \mathrm{~mm}(\mathrm{~T}) \times 20 \mathrm{~mm}(\mathrm{~L})$ were measured under $40 \mathrm{kV}, 30 \mathrm{~mA}$ using monochromatic $\mathrm{CuK} \alpha$-ray with $\mathrm{n}$ filter. The calculation of relative crystallinity used the following Segal method (Segal et al., 1959).

$$
\operatorname{Cr} .(\%)=\frac{I_{200}-I_{a m}}{I_{200}} \times 100
$$

$I_{200}$ : Diffraction strength at $(200)\left(2 \theta=22.8^{\circ}\right)$,

$I_{\mathrm{am}}$ : Diffraction strength of the non-crystalline zone $\left(2 \theta=18^{\circ}\right)$

\section{RESULTS and DISCUSSION}

\subsection{Color change by heat treatment}

Fig. 3 shows the heat-treated woods in three tree specimens at each temperature. All the three species showed marked discoloring over $200^{\circ} \mathrm{C}$. Korean red pine wood showed surface contamination due to the elution of internal resin by heat treatment. The surface contamination of resin could not be observed after the heat treatment at $220^{\circ} \mathrm{C}$, which is believed that resin has been vaporized by high temperature.

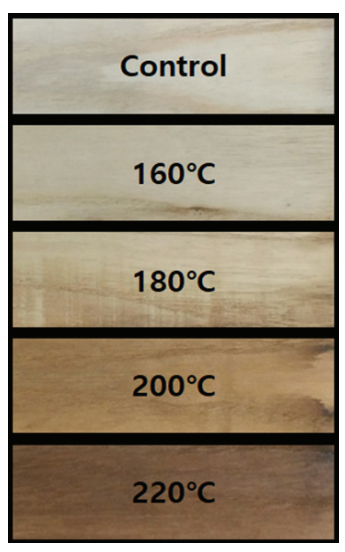

Royal paulownia

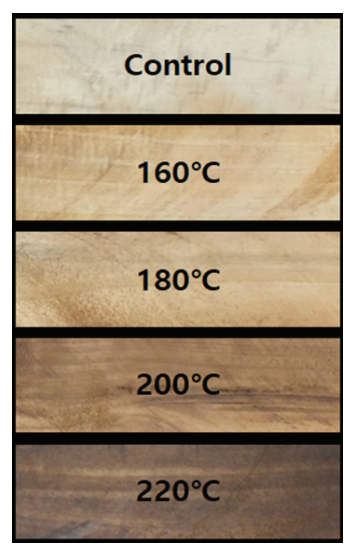

Suwon silver popular

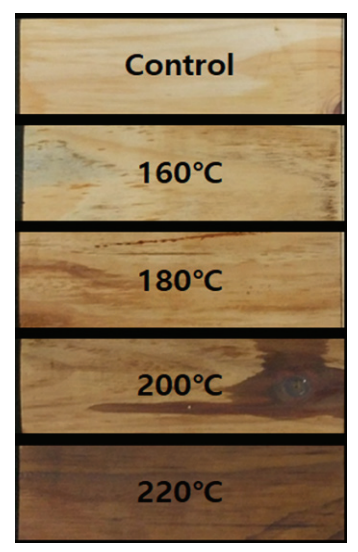

Korean red pine

Fig. 3. Surface images of heat-treated woods at different temperatures. 
Effects of Heat Treatment on the Characteristics of Royal Paulownia (Paulownia tomentosa (Thunb.) Steud.) Wood Grown in Korea

Table 1. Change of $\mathrm{L}^{*} \mathrm{a} \mathrm{b}^{*}$ value of the three wood species at different temperatures.

\begin{tabular}{|c|c|c|c|c|c|}
\hline \multicolumn{6}{|c|}{ Royal paulownia } \\
\hline & Control & $160^{\circ} \mathrm{C}$ & $180^{\circ} \mathrm{C}$ & $200^{\circ} \mathrm{C}$ & $220^{\circ} \mathrm{C}$ \\
\hline $\mathrm{L}^{*}$ & $74.57 \pm 0.1$ & $72.87 \pm 0.9$ & $71.19 \pm 1.9$ & $54.23 \pm 1.6$ & $34.12 \pm 0.2$ \\
\hline$a^{*}$ & $5.86 \pm 0.2$ & $6.66 \pm 0.2$ & $8.91 \pm 0.6$ & $12.63 \pm 0.1$ & $9.44 \pm 0.3$ \\
\hline$b^{*}$ & $15.83 \pm 0.4$ & $17.79 \pm 0.6$ & $21.35 \pm 1.0$ & $24.84 \pm 0.5$ & $14.80 \pm 0.4$ \\
\hline \multicolumn{6}{|c|}{ Suwon silver poplar } \\
\hline & Control & $160^{\circ} \mathrm{C}$ & $180^{\circ} \mathrm{C}$ & $200^{\circ} \mathrm{C}$ & $220^{\circ} \mathrm{C}$ \\
\hline $\mathrm{L}^{*}$ & $72.35 \pm 3.0$ & $77.85 \pm 3.4$ & $74.84 \pm 3.4$ & $43.72 \pm 1.3$ & $31.99 \pm 2.5$ \\
\hline$a^{*}$ & $6.07 \pm 0.2$ & $6.76 \pm 1.1$ & $10.00 \pm 0.3$ & $11.64 \pm 0.2$ & $8.28 \pm 0.8$ \\
\hline$b^{*}$ & $15.17 \pm 0.2$ & $18.68 \pm 1.1$ & $22.71 \pm 0.2$ & $19.05 \pm 0.3$ & $11.54 \pm 1.9$ \\
\hline \multicolumn{6}{|c|}{ Korean red pine } \\
\hline & Control & $160^{\circ} \mathrm{C}$ & $180^{\circ} \mathrm{C}$ & $200^{\circ} \mathrm{C}$ & $220^{\circ} \mathrm{C}$ \\
\hline $\mathrm{L}^{*}$ & $72.611 \pm .2$ & $70.82 \pm 1.0$ & $72.40 \pm 1.0$ & $29.40 \pm 0.9$ & $35.82 \pm 0.9$ \\
\hline$a^{*}$ & $12.87 \pm 1.3$ & $9.68 \pm 0.1$ & $9.68 \pm 0.1$ & $11.07 \pm 0.3$ & $12.44 \pm 0.4$ \\
\hline$b^{*}$ & $31.64 \pm 1.2$ & $24.63 \pm 0.3$ & $24.63 \pm 0.3$ & $7.97 \pm 0.7$ & $17.26 \pm 0.6$ \\
\hline
\end{tabular}

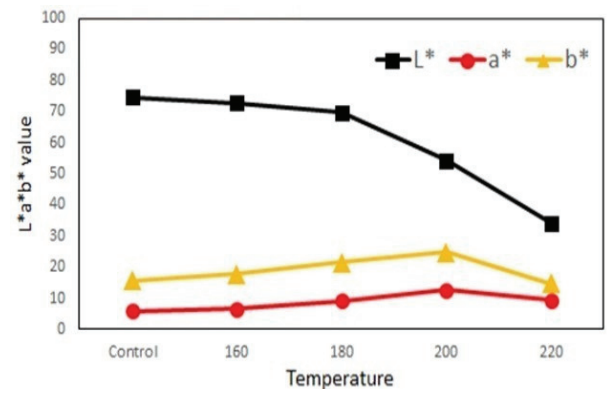

(A) Royal paulownia

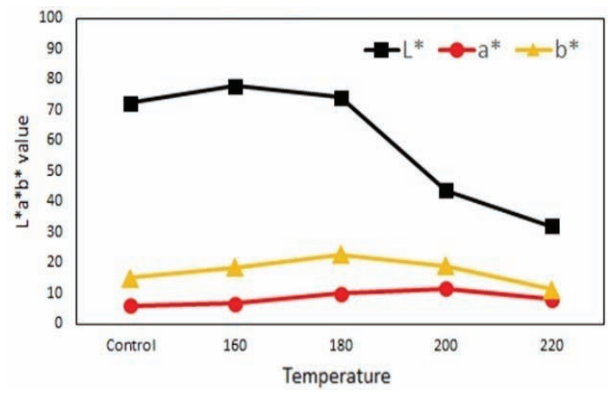

(B) Suwon silver poplar

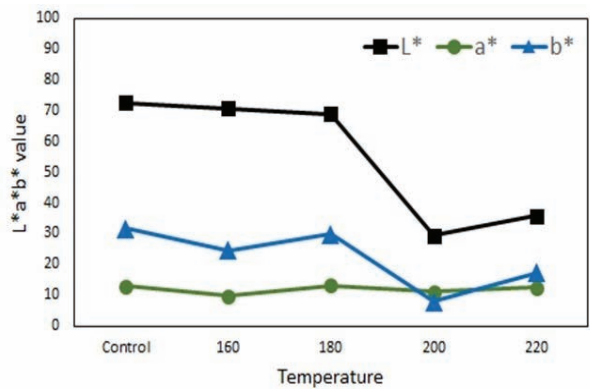

(C) Korean red pine

Fig. 4. Change of $\mathrm{L}^{*} \mathrm{a} \mathrm{b}^{*}$ value of the three wood species at different temperatures.

Table 1 and Fig. 4 show the results of color change of three tree species based on the temperature of the heat treatment. The increase in $\mathrm{L}^{*}$ means the increase in lightness, that of $a^{*}$ means the change of red color, that of $b^{*}$ is the change of yellow color. In all three wood species, the increase in the heat treatment 
Yun Ki, Kim • Gu Joong Kwon • Ah Ran Kim • Hee Soo Lee - Byantaradarsan Purusatama • Seung Hwan Lee $\cdot$ Chun Won Kang $\cdot$ Nam Hun Kim

Table 2. Color change $\left(\triangle E^{*}\right)$ of the three wood species after heat treatment

\begin{tabular}{cccc}
\hline & \multicolumn{1}{c}{$\Delta \mathrm{E}^{*}$ value (Classification according to N.B.S.) } \\
\hline \hline Condition & Royal paulownia & Suwon silver poplar & Korean red pine \\
\hline Control & - & - & 4.51 \\
$160^{\circ} \mathrm{C}$ & $\begin{array}{c}1.26 \\
\text { (slight) }\end{array}$ & $\begin{array}{c}5.21 \\
\text { (appreciable) }\end{array}$ & $\begin{array}{c}3.28 \\
\text { (appreciable) }\end{array}$ \\
\hline $180^{\circ} \mathrm{C}$ & $\begin{array}{c}21.23 \\
\text { (very much) }\end{array}$ & $\begin{array}{c}3.87 \\
\text { (appreciable) }\end{array}$ \\
\hline $200^{\circ} \mathrm{C}$ & $\begin{array}{c}40.62 \\
\text { (very much) }\end{array}$ & $\begin{array}{c}29.11 \\
\text { (very much) }\end{array}$ \\
\hline $220^{\circ} \mathrm{C}$ & $\begin{array}{c}40.47 \\
\text { (very much) }\end{array}$ & $\begin{array}{c}43.52 \\
\text { (very much) }\end{array}$ \\
\hline
\end{tabular}

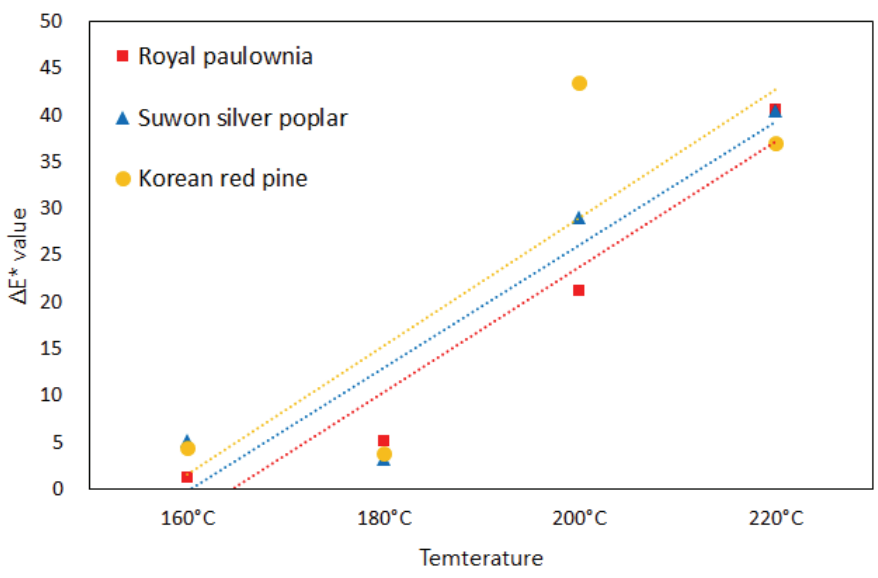

Fig. 5. $\triangle \mathrm{E}^{*}$ values of the three wood species after heat treatment.

temperature results in the decrease of $\mathrm{L}^{*}$, which signifies lightness, and over $200^{\circ} \mathrm{C}$, lightness fell drastically and visual-inspection showed dark color as well.

With Royal paulownia wood and Suwon silver poplar, $a^{*}, b^{*}$ increased with the increase in heat treatment temperature, but with Korean red pine wood, $\mathrm{b}^{*}$ value showed a decreasing tendency over $200^{\circ} \mathrm{C}$. There are many previous studies on heat treatment temperature and color change (Aydemir et al., 2014; Bekhta and Niemz, 2003; Brischke et al., 2007; Hidayat et al., 2015, 2016, 2017b; Yoon et al., 2008, 2009). Particularly, Bekhta and Niemz (2003) reported from the heat treatment test of Korean spruce wood that $\mathrm{L}^{*}$ and $\mathrm{b}^{*}$ values decreased and $\mathrm{a}^{*}$ value increased. Hidayat et al. (2017b) surveyed the public's preference of the color change on the Royal paulownia wood and nut pine wood surface by treatment temperature and reported that they considered the surface of heat-treated wood at 180 to $200^{\circ} \mathrm{C}$ most beautiful, a result that has been confirmed by the result of the present study.

$\mathrm{L}^{*} \mathrm{a}^{*} \mathrm{~b}^{*}$ shows the color change and cannot express an absolute amount of that change, but $\triangle E^{*}$ is an absolute value, through which the amount of color change between two specimens each of which the color change occurred in opposite directions (Han and Cho, 2005). Table 2 and Fig. 5 show the amount of color 
Effects of Heat Treatment on the Characteristics of Royal Paulownia (Paulownia tomentosa (Thunb.) Steud.) Wood Grown in Korea

Table 3. Change of density and mass loss of the three wood species after heat treatment

\begin{tabular}{ccccccc}
\hline & \multicolumn{2}{c}{ Royal paulownia } & \multicolumn{2}{c}{ Suwon silver poplar } & \multicolumn{2}{c}{ Korean red pine } \\
\cline { 2 - 7 } Content & $\begin{array}{c}\text { Density } \\
\left(\mathrm{g} / \mathrm{cm}^{3}\right)\end{array}$ & $\begin{array}{c}\text { Mass loss } \\
(\%)\end{array}$ & $\begin{array}{c}\text { Density } \\
\left(\mathrm{g} / \mathrm{cm}^{3}\right)\end{array}$ & $\begin{array}{c}\text { Mass loss } \\
(\%)\end{array}$ & $\begin{array}{c}\text { Density } \\
\left(\mathrm{g} / \mathrm{cm}^{3}\right)\end{array}$ & $\begin{array}{c}\text { Mass loss } \\
(\%)\end{array}$ \\
\hline \hline Control & $0.26 \pm 0.02$ & - & $0.55 \pm 0.04$ & - & $0.50 \pm 0.06$ & - \\
$160^{\circ} \mathrm{C}$ & $0.26 \pm 0.01$ & $1.8 \pm 0.27$ & $0.53 \pm 0.03$ & $1.5 \pm 0.14$ & $0.49 \pm 0.05$ & $2.2 \pm 0.32$ \\
$180^{\circ} \mathrm{C}$ & $0.26 \pm 0.01$ & $8.6 \pm 0.27$ & $0.51 \pm 0.04$ & $2.8 \pm 0.18$ & $0.47 \pm 0.04$ & $3.5 \pm 0.25$ \\
$200^{\circ} \mathrm{C}$ & $0.25 \pm 0.02$ & $11.4 \pm 0.29$ & $0.49 \pm 0.01$ & $5.8 \pm 0.46$ & $0.45 \pm 0.03$ & $6.4 \pm 0.30$ \\
$220^{\circ} \mathrm{C}$ & $0.23 \pm 0.04$ & $15.0 \pm 0.76$ & $0.49 \pm 0.04$ & $13.6 \pm 1.62$ & $0.45 \pm 0.04$ & $9.2 \pm 0.54$ \\
\hline
\end{tabular}
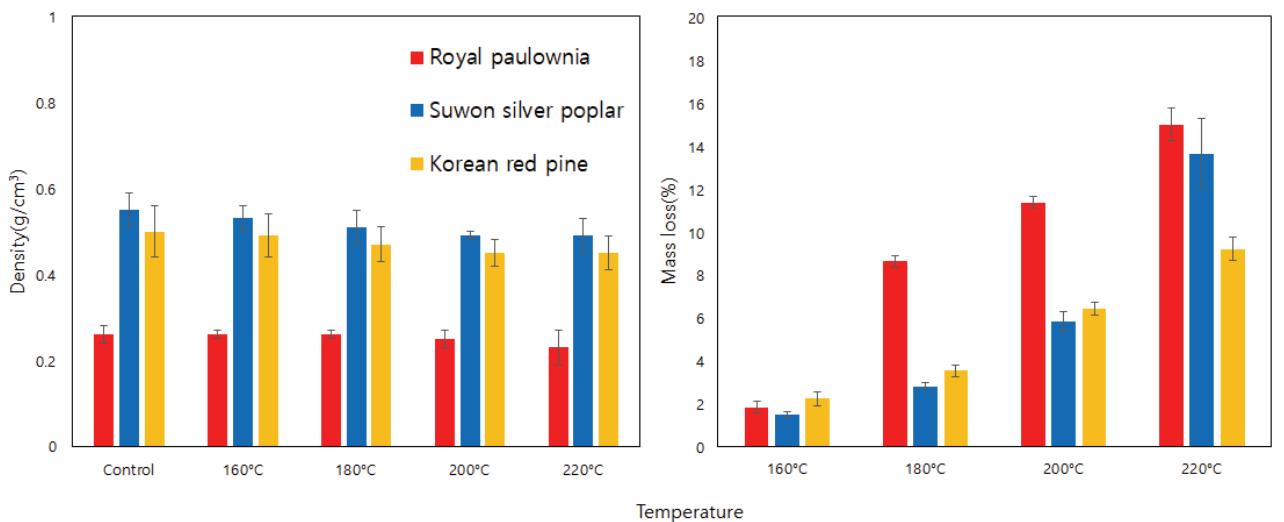

Fig. 6. Change of density and mass loss of the three wood species after heat treatment.

change in three tree species by temperature $\left(\triangle \mathrm{E}^{*}\right)$. Over $200^{\circ} \mathrm{C}$, all three species showed a drastic displacement of $\triangle \mathrm{E}^{*}$, which corresponds to "very much" under the amount of color change categories by N.B.S. (Han and Cho, 2005). At $160^{\circ} \mathrm{C}$, Royal paulownia wood showed a slight change whereas Suwon silver poplar wood and Korean red pine wood showed a considerable change. With higher temperature at $180^{\circ} \mathrm{C}$, Royal paulownia wood showed an appreciable change. Therefore, compared to the other two species, Royal paulownia wood showed color change at a somewhat higher temperature. Many researchers have reported the change of $\triangle \mathrm{E}^{*}$ by the increase of heat treatment temperature and duration (Brischke et al., 2007; Hidayat et al., 2015, 2016, 2017b; Lim et al., 2014; Ra et al., 2012; Shi et al., 2011; Yoon et al., 2008, 2009). Also, the increase of $\triangle \mathrm{E}^{*}$ resulted in the decrease of MOR and MOE (Bekhta and Niemz, 2003; Brischke et al., 2007; Hidayat et al., 2016) as well as the increase of the volume contraction ratio and the decrease in density, equilibrium moisture content, and the amount of moisture absorption (Hidayat et al., 2016) so that it is believed that there is a close relation between color change and wood properties.

\subsection{Density and weight reduction change by heat treatment}

Table 3 and Fig. 6 show the density change and weight reduction of three wood species by heat treatment. The density of non-treated wood is $0.26 \mathrm{~g} / \mathrm{cm}^{3}$ for Royal paulownia wood, $0.50 \mathrm{~g} / \mathrm{cm}^{3}$ for Korean pine, 
Yun Ki, Kim • Gu Joong Kwon • Ah Ran Kim • Hee Soo Lee - Byantaradarsan Purusatama • Seung Hwan Lee $\cdot$ Chun Won Kang $\cdot$ Nam Hun Kim

and $0.55 \mathrm{~g} / \mathrm{cm}^{3}$ for Suwon silver poplar. With the increase in heat treatment temperature, the density of all three wood species decreased somewhat, by about a $10 \%$ decrease in density at $220^{\circ} \mathrm{C}$. Particularly, Royal paulownia wood showed relatively stable properties with little density change at $180^{\circ} \mathrm{C}$. Weight reduction also increased in all three species along with the temperature increase, and the largest weight reduction was observed in Royal paulownia wood. Particularly, Royal paulownia wood showed considerable weight reduction from $180^{\circ} \mathrm{C}$, and Suwon silver poplar wood showed a drastic weight reduction at $220^{\circ} \mathrm{C}$. Korean red pine wood, on the other hand, showed relatively lower weight reduction.

Generally, it has been known that low moisture content, the vaporization of extracts contained in wood, the decomposition of hemicellulose in wood and the vaporization of the decomposited materials cause the density and weight reduction by heat treatment (Poncsak et al. 2005; Yildiz et al. 2006; Gunduz et al., 2009; Kim, 2016). For extracts in wood are highly volatile with lower amount of molecules compared to the other components, and thus, the decomposition at low temperature $\left(120^{\circ} \mathrm{C}\right.$ to $\left.180^{\circ} \mathrm{C}\right)$ is linked to these extracts (Shebani et al. 2008; Kim, 2016). Hemicellulose is pyrolyzed at over $180^{\circ} \mathrm{C}$ (Liang and Wang, 2017), and the reduction of hydrophile hemicellulose decreases the absorptivity, resulting in the increase in dimensional stability (Korkut et al., 2008). Thus, it is believed that wood species with high hemicellulose content show high weight reduction during the heat treatment at over $180^{\circ} \mathrm{C}$.

According to Chong and Park (2008), the hemicellulose content in Royal paulownia wood $17.8 \%$, that of Korean red pine wood and Suwon silver poplar wood is $12.9 \%$ and $26.9 \%$, respectively, and the extract content in Royal paulownia wood by hot water is $8.8 \%$, and that in Korean red pine wood and Suwon silver poplar wood is $1.6 \%$ and $3.6 \%$, respectively. Thus, it is believed that the reason why Royal paulownia wood shows low density change and high weight reduction by heat treatment compared to the other species is due to the differences in chemical content, such as extracts, hemicellulose and properties, etc.

\subsection{Relative crystallinity}

Fig. 7 shows $\mathrm{X}$-ray diffraction strength curves that measured the heat-treated woods from three species. This confirmed that in all three species, the heat treatment increased the strength of (1-10), (110), and (200), key surfaces of cellulose crystallization. Table 4 shows the relative crystallinity results from the X-ray diffraction strength curves of three tree species before and after the heat treatment. On the non-treated specimens, Royal paulownia wood showed the lowest relative crystallinity, and Suwon silver poplar wood showed the highest relative crystallinity. All three tree species showed a slight tendency in the increase of relative crystallinity as the temperature increased. Particularly, heat-treated Royal paulownia wood showed the highest increase in relative crystallinity compared to that of the non-treated specimen.

According to Bhuiyan et al. (2000), the relative crystallinity of wood cellulose increased in the initial phase of the heat treatment between 180 and $220^{\circ} \mathrm{C}$, and Hidayat et al. (2016) reported that the relative crystallinity of cellulose increased somewhat by heat treatment and over for two hours of the treatment, it tended to decrease. Furthermore, Kubojima et al. (1998) and Kocaefe et al. (2008) showed that the relative crystallinity of cellulose would increase by short-term heat treatment and affect the change of dynamic properties.

Accordingly, the present study confirmed a slight increase in relative crystallinity by heat treatment, which is a key factor in wood properties such as equilibrium moisture content (Dwiant et al., 1997; Kubojima et al., 
Effects of Heat Treatment on the Characteristics of Royal Paulownia (Paulownia tomentosa (Thunb.) Steud.) Wood Grown in Korea

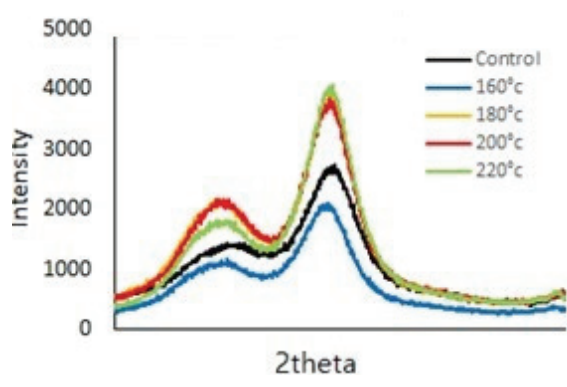

(A) Royal paulownia

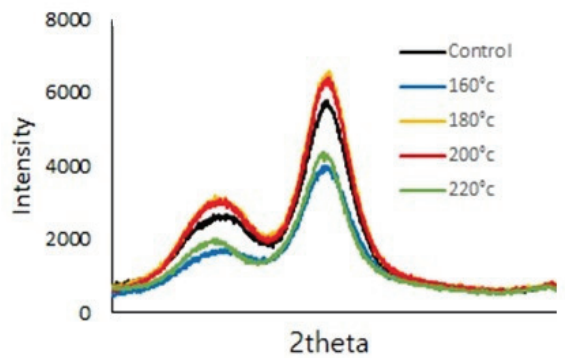

(B) Suwon silver poplar

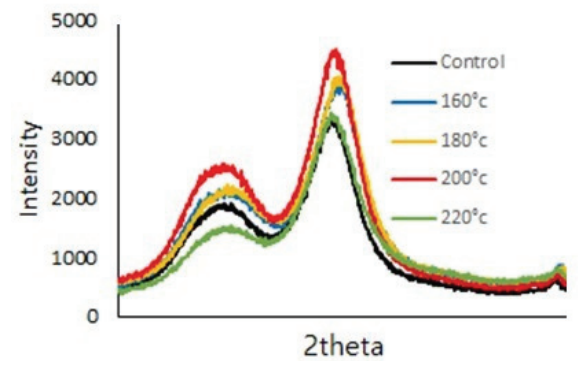

(C) Korean red pine

Fig. 7. X-ray diffractograms of the three wood species at different temperatures.

Table 4. Relative crystallinity of the three wood species after heat treatment

\begin{tabular}{cccc}
\hline Condition & Royal paulownia & Suwon silver poplar & Korean red pine \\
\hline \hline Control & $53.5 \pm 0.1$ & $66.7 \pm 4.6$ & $59.3 \pm 2.9$ \\
$160^{\circ} \mathrm{C}$ & $57.9 \pm 0.9$ & $64.1 \pm 2.6$ & $60.2 \pm 3.5$ \\
$180^{\circ} \mathrm{C}$ & $61.1 \pm 0.3$ & $68.4 \pm 2.7$ & $58.6 \pm 1.2$ \\
$200^{\circ} \mathrm{C}$ & $59.6 \pm 4.0$ & $68.0 \pm 0.1$ & $62.2 \pm 3.9$ \\
$220^{\circ} \mathrm{C}$ & $66.5 \pm 4.8$ & $68.2 \pm 3.9$ & $64.1 \pm 1.6$ \\
\hline
\end{tabular}

1998; Ishiguri et al., 2003) and MOE(Hirai et al., 1972; Inoue and Norimoto, 1991; Ishiguri et al., 2003). And therefore, further review on temperature, duration, and types of tree species would be required.

\section{CONCLUSION}

The comparison and analysis results of the heat treatment properties of Royal paulownia wood to those of Suwon silver poplar and Korean red pine are as follows.
1. The lightness $\left(\mathrm{L}^{*}\right)$ of Royal paulownia wood, Suwon silver poplar wood, and Korean red pine wood decreased with the increase in the temperature of the heat treatment. While the red-green chromaticity $\left(\mathrm{a}^{*}\right)$ and the yellow-blue chromaticity $\left(b^{*}\right)$ showed little change with the increase in the heat treatment temperature, the yellow-blue chromaticity(b*) of Korean red pine wood drastically decreased from over $200^{\circ} \mathrm{C}$. The color change $\left(\Delta E^{*}\right)$ of Royal paulownia wood showed a marked increase from $180^{\circ} \mathrm{C}$, and that 
Yun Ki, Kim • Gu Joong Kwon • Ah Ran Kim • Hee Soo Lee • Byantaradarsan Purusatama • Seung Hwan Lee $\cdot$ Chun Won Kang $\cdot$ Nam Hun Kim

of Suwon silver poplar and Korean red pine wood showed a marked increase from $160^{\circ} \mathrm{C}$. In all three species, $\Delta \mathrm{E}^{*}$ markedly increased from over $200^{\circ} \mathrm{C}$, showing similar $\Delta \mathrm{E}^{*}$ at $220^{\circ} \mathrm{C}$.

2. The density of the wood specimens decreased by about $10 \%$ due to the heat treatment at $220^{\circ} \mathrm{C}$, and at $160-180^{\circ} \mathrm{C}$, there was no density change in Royal paulownia wood. There was the largest weight reduction on Royal paulownia wood, and particularly, from over $180^{\circ} \mathrm{C}$, the weight of Royal paulownia wood drastically decreased.

3. The relative crystallinity of all wood specimens showed some increase as the temperature of heat treatment increased, and compared to its nontreated specimen, Royal paulownia wood showed the largest increase in relative crystallinity.

As such, the study identified the change in color, density, and relative crystallinity on Royal paulownia, Suwon silver poplar and Korean red pine woods, and the data on such changes of the properties would be used as basic data for the application of these woods to practical usage in the wood industry.

\section{ACKNOWLEDGMENT}

This research was supported by the National Research Foundation of Korea in 2016 (Ministry of Education) (NO. 2016R1D1A1B01008339) and in 2018 (Ministry of Education) (NO. 2018R1A6A1A03 025582).

\section{REFERENCES}

Aydemir, D., Gunduz, G., Ozdenm, S. 2014. The influence of thermal treatment on color response of wood materials. Color Research and Application 37(2): 148-153.

Bekhta, P., Niemz, P. 2003. Effect of high temperature on the change in colour, dimensional stability and mechanical properties of spruce wood. Holzforschung 57(5): 539-546.

Bhuiyan, M.T.R., Hirai, N., Sobue, N. 2000. Changes of crystallinity in wood cellulose by heat treatment under dried and moist conditions. Journal of Wood Science 46(6): 431-436.

Brischke, C., Welzbacher, C.R., Brandt, K., Rapp, A.O. 2007. Quality control of thermally modified timber: Interrelationship between heat treatment intensities and CIE $L * a * b *$ color data on homogenized wood samples. Holzforschung 61: 19-22.

Cho, B.G., Hwang, S.W., Kang, H.Y., Lee, W.H. 2015. Change of dimensional stability of thermally compressed Korean pine (Pinus koraiensis Sieb. et Zucc.) wood by heat treatment. Journal of the Korean Wood Science and Technology 43(4): 470-477.

Chong, S.H., Park, B.S. 2008. Wood properties of the useful tree species grown in Korea. Korea Forest Research Institute.

Dwiant, W., Inoue, M., Norimoto, M. 1997. Fixation of compressive deformation of wood by heat treatment. Mokuzai Gakkaishi 43: 303-309.

Gunduz, G., Korkut, S., Aydemir, D., Bekar, I. 2009. The density, compression strength and surface hardness of heat treated hornbeam(Carpinus betulus) wood. Maderas. Ciencia y tecnologia 11(1): 61-70.

Han, E.J., Cho, J.Y. 2005. Color analysis of printed silk with digital textile printing method. Journal of the Korean Society of Design Culture 11(2): 126-134.

Hidayat, W., Jang, J.H., Park, S.H., Febrianto, F., Lee, S.H., Kim, N.H. 2015. Effect of temperature and clamping during heat treatment on physical and mechanical properties of okan (Cylicodiscus gabunensis [Taub.] Harms). BioResources 10(4): 6961-6974.

Hidayat, W., Qi, Y., Jang, J.H., Febrianto, F., Kim, N.H. 2017a. Effect of mechanical restraint on the 
Effects of Heat Treatment on the Characteristics of Royal Paulownia (Paulownia tomentosa (Thunb.) Steud.) Wood Grown in Korea

properties of heat-treated Pinus koraiensis and Paulownia tomentosa woods. BioResources 12(4): 7539-7551.

Hidayat, W., Qi, Y., Jang, J.H., Febrianto, F., Lee, S.H., Kim, N.H. 2016. Effect of treatment duration and clamping on the properties of heat-treated okan wood. BioResources 11(4): 10070-10086.

Hidayat, W., Qi, Y., Jang, J.H., Park, B.H, Banuwa, I.S.B., Febrianto, F., Kim, N.H. 2017b. Color change and consumer preferences towards color of heat-treated korean white pine and royal paulownia woods. Journal of the Korean Wood Science and Technology 45(2): 213-222.

Hirai, N., Sobue, N., Asano, I. 1972. Studies on piezoelectric effect of wood IV. Effects of heat treatment on cellulose crystallilties and piezoelectric effect of wood. Mokuzai Gakkaishi 18: 535-542.

Hong, B.H. 1985. The dynamic mechanical properties of Paulownia coreana used for sounding boards. Journal of the Korean Wood Science and Technology 13(3): 34-40.

Inoue, M., Norimoto, M. 1991. Permanent fixation of compressive deformation in wood by heat treatment. Wood Research and Technical Notes 27: 31-40. Ishiguri, F., Matsui, M., Andoh, M., Yokota, S., Yoshizawa, N. 2003. Time-course changes of chemical and physical properties in sugi (Cryptomeria japonica D. Don) logs during smoke heating. Wood and Fiber Science 35(4): 585-593.

Kang, C.W., Lim, H.M., Kang, H.Y. 2015. Investigation on the oil heat treatment of domestic utilization species I-The color change of larch and paulownia wood specimens treated at $200^{\circ} \mathrm{C}$. Journal of the Korea Furniture Society 26(2): 138-144.

Kim, K.M., Park, J.H., Park, B.S., Son, D.W., Park, J.S., Kim, W.S., Kim, B.N., Shim, S.R. 2009. Physical and mechanical properties of heat-treated domestic cedar. Journal of the Korean Wood
Science and Technology 37(4): 330-339.

Kim, K.M., Park, J.H., Park, B.S., Son, D.W., Park, J.S., Kim, W.S., Kim, B.N., Shim, S.R. 2010. Physical and mechanical properties of heat-treated domestic yellow poplar. Journal of the Korean Wood Science and Technology 38(1): 17-26.

Kim, S.I. 1997. New landscaping tree-Paulownia wood(Korean). Landscaping tree. 39(7): 18-20.

Kim, Y.S. 2016. Research trend of the heat-treatment of wood for improvement of dimensional stability and resistance to biological degradation. Journal of the Korean Wood Science and Technology 44(3): 457-476.

Kocaefe, D., Poncsak, S., Boluk, Y. 2008. Effect of thermal treatment on the chemical composition and mechanical properties of birch and aspen. BioResources 3(2): 517-537.

Korkut, D.S., Korkut, S., Bekar, I., Budakçi, M., Dilik, T., Çakicier, N. 2008. The Effects of Heat Treatment on the Physical Properties and Surface Roughness of Turkish Hazel (Corylus colurna L.) Wood. International Journal of Molecular Science. 9(9): 1772-1783.

Kubojima, Y., Okano, T., Ohta, M. 1998. Vibrational properties of sitka spruce heat- treated in nitrogen gas. Journal of Wood Science 44(1): 73-77.

Kuroiwa, Y. 2010. Paulownia, The Savior of Environment. Kaiseisha Press. Japan.

Lee, W.H., Park, B.S., Chong, S.H., Kang, H.Y., Hwang, K.H., Byeon, H.S. 2008. Study on physical properties of domestic species $\mathbb{I I}$ : sorption, thermal, electrical and acoustic properties of Lifiodendron tulipifera, Betula costata, Paulownia coreana. Journal of the Korean Wood Science and Technology 36(6): 1-12.

Liang, T., Wang, L. 2008. Thermal treatment of poplar hemicelluloses at $180^{\circ} \mathrm{C}$ to $220^{\circ} \mathrm{C}$ under nitrogen atmosphere. BioResources 12(1): 1128-1135.

Lim, H.M., Hong, S.H., Kang, H.Y. 2014. Investigation 
Yun Ki, Kim • Gu Joong Kwon • Ah Ran Kim • Hee Soo Lee - Byantaradarsan Purusatama • Seung Hwan Lee $\cdot$ Chun Won Kang $\cdot$ Nam Hun Kim

of the color change and physical properties of heat-treated Pinus koraiensis square lumbers. Journal of the Korean Wood Science and Technology 42(1): 13-19.

Park, Y.G., Eom, C.D., Park, J.H., Chang, Y.S., Kim, K.M., Kang, C.W., Yeo, H.M. 2012. Evaluation of physical properties of Korean pine (Pinus koraiensis Siebold \& Zucc.) lumber heat-treated by superheated steam. Journal of the Korean Wood Science and Technology 40(4): 257-267.

Poncsak, S., Kocaefe, D., Bouazara, M., Pichette, A. 2005 Effect of high temperature treatment on the mechanical properties of birch (Betula papyrifera). Wood Science and Technology 66(1): 39-49.

Qi, Y., Jang, J.H., Hidayat, W., Lee, A.H., Lee, S.H., Kim, N.H. 2016a. Carbonization of reaction wood from Paulownia tomentosa and Pinus densiflora branch woods. Wood Science and Technology. 50(5): 973-987.

Qi, Y., Jang, J.H., Hidayat, W., Lee, A.H., Park, S.H., Lee, S.H., Kim, N.H. 2016b. Anatomical characteristics of Paulownia tomentosa root wood. Journal of the Korean Wood Sciences and Technology 44(2): 157-165.

Qi, Y., Jang, J.H., Park, S.H., Kim, N.H. 2014. Anatomical and physical characteristics of Korean paulownia (Paulownia coreana) branch wood. Journal of the Korean Wood Science and Technology 42(5): 510-515.

Qi, Y., Yang, C., Hidayat, Jang, J.H., Kim, N.H. 2016c. Solid bioenergy properties of Paulownia tomentosa grown in Korea. Journal of the Korean Wood Science and Technology 44(6): 890-896.

Ra, J.B., Kim, K.B., Leem, K.H. 2012. Effect of heat treatment conditions on color change and termite resistance of heat-treated wood. Journal of the
Korean Wood Science and Technology 40(6): 370-377.

Segal, L., Creely, J.J., Martin, A.E., Conrad, C.M. 1959. An empirical method for estimating the degree of crystallinity of native cellulose using the X-ray diffractometer. Textile research Journal 29: 786-794.

Shebani, A.N., Van Reenen, A.J., Meincken, M. 2008. The effect of wood extractives on the termal stability of different wood species. Thermochimica Acta 471:43-50.

Shi, Q., Bao, F.C., Lu, J.X., Jiang, J.H. 2011. Effect of heat treatment temperature on the colour of Okan wood. Advanced Materials Research 214(1): 531-534.

Yildiz, S., Gezer, E.D., Yildiz, U.C. 2006. Mechanical and chemical behavior of sprucewood modified by heat. Building and Environment 41(12): 1762-1766.

Yoo, T. K., Jung, H. S. 1997. Effect of moisture contents and density of Paulownia tomentosa on acoustical properties. Journal of the Korean Wood Science and Technology 25(2): 61-66.

Yoon, K.J., Eom, C.D., Park, J.H., Kim, H.Y., Choi, I.G., Lee, J.J., Yeo, H.M. 2009. Color control and durability improvement of yellow polar (Liriodendron tulipifera) by heat treatments. Journal of the Korean Wood Science and Technology 37(6): 487-496.

Yoon, K.J., Eom, C.D., Park, J.H., Lee, Y.W., Choi, iI.G., Lee, J.J., Yeo, H.W. 2008. Control of discoloration of cedar wood (Cryptomeria japonica) by heat and UV treatment. Journal of the Korean Wood Science and Technology 36(6): 33-40. 
Effects of Heat Treatment on the Characteristics of Royal Paulownia (Paulownia tomentosa (Thunb.) Steud.)

Wood Grown in Korea

\title{
APPENDIX
}

\author{
(Korean Version)
}

\section{국산 참오동나무재의 열처리 특성}

요약 : 본 연구에서는 국산 참오동나무재의 열처리에 의한 재질특성의 변화를 조사하였다. 비교를 위하여 은사시나무와 소나무재의 열처리 특성을 조사, 검토하였다. 세 공시수종의 목재시험편을 $160^{\circ} \mathrm{C}, 180^{\circ} \mathrm{C}, 200^{\circ} \mathrm{C}$ 및 $220^{\circ} \mathrm{C}$ 의 전기로 내에서 2 시간 열처리 후, 재색변화 $\left(\mathrm{L}^{*} \mathrm{a} \mathrm{b}^{*}\right)$, 밀도, 중량감소율 및 셀룰로오스의 상대결정화도를 측정하였다. 재색변화 측정결과, 명도 $\left(\mathrm{L}^{*}\right)$ 는 세 공시수종 목재 모두 $200^{\circ} \mathrm{C}$ 이상에서 크게 감소하였다. 참오동나무재와 은사시나무재의 적-녹색도 $\left(\mathrm{a}^{*}\right)$ 와 황청색도 $\left(\mathrm{b}^{*}\right)$ 는 열처리 온도증가에 따른 차이는 거의 없었으나, 소나무재의 $\mathrm{b}^{*}$ 는 $200^{\circ} \mathrm{C}$ 이후 감소하였다. 참오동나무재의 재색변화량 $\left(\Delta \mathrm{E}^{*}\right)$ 은 $160^{\circ} \mathrm{C}$ 열처리에서는 거의 없었고 $180^{\circ} \mathrm{C}$ 이상에서 크게 나타났으나, 은사시나무와 소나무재는 $160^{\circ} \mathrm{C}$ 에서 도 재색변화가 크게 나타났다. 참오동나무재의 밀도는 $160 ~ 180^{\circ} \mathrm{C}$ 열처리에서는 거의 변화가 없었고, 중량감소율은 참오동나 무재가 가장 크게 나타났다. 열처리온도 증가에 따라 세 수종의 목재의 중량감소율과 상대결정화도는 증가하였으나 밀도는 다소 감소하였다. 결론적으로 참오동나무재는 색변화 온도, 중량감소율 및 상대결정화도 증가량이 비교수종 목재와 다른 특성 을 나타났다.

\section{1. 서 론}

현재, 우리나라는 국내 목재사용량의 83\%이상을 수입재에 의존하고 있고, 2050년까지 국산재 자급율 $50 \%$ 를 목표로 하고 있어, 경제수종 및 속성수종의 조림 및 이용방안 확대를 위한 연구가 중요하다.

오동나무는 소나무와 함께 우리 민족의 문화정서에 맞는 소중한 목재자원으로, 국내 자생 수종 중 가장 성장 속도가 빠르며 치수안정성, 내구성이 우수하여 전통적으로 악기용재 및 가구용재 등 생활용재로 이용되어 온 비교적 부가가치가 높은 유용 수종에 속한다. 오동나무속은 한국, 중국, 일본 및 동남아시아 지역에서 생육하고 있고, 수고는 $15 \sim 20 \mathrm{~m}$, 흥고직경은 $80 \mathrm{~cm}$ 까지 자라는 교목이다. 오동나무속은 식재 10년 이내에 목재로서의 이용이 가능한 정도로 성장하며, 가볍고 연하여 가공성이 매우 용이하다. 국내 자생하는 오동나무 중 이용가치가 높은 것은 오동나무(Paulownia coreana UYEKI)와 참오동나무 (Paulownia tometosa (Thunb.) Steud.)이다. 오동나무와 참오동나무는 속성수종으로써 비교적 재질이 우수하여 용도가 다양하 고 바이오매스자원으로도 이용 가치가 매우 높은 수종으로 간주된다(Kim, 1997; Kuroiwa, 2010).

국산 오동나무재의 이용과 관련해서는 음향적 특성을 중심으로 한 물리적 성질에 관한 연구(Hong, 1985; Yoo and Jung, 1997; Lee et al., 2008)가 주로 수행되어 왔고, 최근 저자 등(Qi et al., 2014, 2016a, 2016b, 2016c)은 오동나무재의 재질평가 및 바이오매스자원으로의 활용을 위하여 참오동나무재의 수간, 가지, 뿌리 부위의 해부학적, 물리적, 역학적 및 탄화 특성을 조사, 검토하였다.

최근 목재의 흡습성 및 치수안정성, 내후성, 재색 등을 향상시키기 위하여 목재의 열처리방법이 널리 이용되고 있다(Kim, 2016). 국산재를 이용한 열처리 목재에 관한 연구도 다양하게 수행되어 왔다(Cho et al., 2015; Kang et al., 2015; Kim et al., 2009, 2010; Lim et al., 2014; Park et al., 2012; Hidayat et al., 2017a, 2017b; Yoon et al., 2008, 2009). 하지만 이러한 열처리 방법을 국내 유용 목재자원인 참오동나무재에 적용하여 연구한 예는 많지 않다. Kang et al.(2015)은 낙엽송과 오동나무 를 $200^{\circ} \mathrm{C}$ 에서 오일 열처리하여 표면 재색변화를 관찰한 결과 오동나무가 낙엽송에 비해 비교적 재색변화가 적다고 발표하였다. Hidayat et al.(2017b)은 참오동나무 열처리를 통해 재색변화를 비교하고, 심미적 특성이 뛰어난 열처리 방법 및 온도를 설문조사 를 통해 도출하였다. 또한 Hidayat et al.(2017a)은 참오동나무재를 클램프를 이용하여 구속한 상태에서 열처리하면 구속하지 않은 목재보다 물리적, 역학적 성질의 감소가 작다고 보고하였다. 따라서 열처리 목재의 재질 평가에는 미적관점에서 열처리에 의한 수종별, 열전달 매질(공기, 질소 등), 열처리온도 및 시간에 따른 재색변화가 가장 중요한 지표로 판단되며, 이때 역학적 특성에 영향을 미치는 중량변화, 셀룰로오스 결정화도 등의 분석도 중요한 자료로 생각된다.

본 연구에서는 국내산 속성수종으로 부가가치가 높은 참오동나무재의 이용방안 확대의 주요 기초 자료를 제공하고자, 참오동 나무재의 열처리에 의한 색변화, 중량 및 밀도변화, 셀룰로오스의 상대결정화도 특성을 조사하였다. 또한 활엽수 속성수재의 하나인 은사시나무와 침엽수재로서 국내 대표 수종인 소나무재를 이용하여 열처리 특성을 비교, 검토하였다. 
Yun Ki, Kim • Gu Joong Kwon • Ah Ran Kim • Hee Soo Lee • Byantaradarsan Purusatama •

Seung Hwan Lee $\cdot$ Chun Won Kang $\cdot$ Nam Hun Kim

\section{2. 재료 및 방법}

\section{1 공시재료}

본 연구에서는 강원대학교 학술림에서 수령 11 15년, 흥고직경 약 $30 \mathrm{~cm}$ 의 참오동나무(Royal paulownia, Paulownia tomentosa (Thunb.) Steud.) 3본을 채취하여 사용하였다. 비교를 위하여 강원대학교 구내림에서 채취한 수령 약 25년, 흥고직 경 약 $35 \mathrm{~cm}$ 의 은사시나무(Suwon silver poplar, Populus tementiglandulosa T. Lee)와 국립산림과학원으로부터 제공받은 것으로 삼척에서 채취한 수령 약 50 년, 흥고직경 약 $40 \mathrm{~cm}$ 의 소나무(Korean red pine, Pinus densiflora Siebold \& Zucc.) 변재부 판재를 공시재료로 이용하였다.

\section{2 실험방법}

\section{2 .1 열처리}

공시수종의 전건시료를 $160 \mathrm{C}^{\circ}, 180 \mathrm{C}^{\circ}, 200 \mathrm{C}^{\circ}, 220 \mathrm{C}^{\circ}$ 에서 2 시간 동안 열처리하였으며, $2 \mathrm{C}^{\circ} / \mathrm{min}$ 조건으로 승온 하였다(Fig. 1). 실험에 적용된 시료제작 및 열처리 스케줄은 열처리 과정 중 튀틀림이나 할렬이 적으며 우수한 치수안정성과 내구성을 나타내는 선행연구 결과를 참고하였다(Hidayat et. al., 2017a).

\section{2 .2 재색변화 측정}

세 수종의 열처리에 의한 재색변화는 색차계(NR110, 3nh, China)를 사용하여 측정하였다. 재색변화 측정을 위한 시편은 $50 \mathrm{~mm}(\mathrm{~T}) \times 20 \mathrm{~mm}(\mathrm{R}) \times 160 \mathrm{~mm}(\mathrm{~L})$ 크기로 제작한 후 열처리하였다. 시편의 3지점에서 재색을 측정하였으며(Fig. 2), 재색 수치의 표현은 국제조명위원회(Commission Internationale de I'Eclairage)의 CIE-L"a a b 색공간 측정법을 사용하였다(Han and Cho, 2005). $\mathrm{L}^{*}$ 은 명도의 차이를 나타낸 것이고, $\mathrm{a}^{*}$ 와 $\mathrm{b}^{*}$ 는 색의 방향을 의미한다. -a* 녹색을, $+\mathrm{a}^{*}$ 는 적색을 나타내며, $-\mathrm{b}^{*}$ 는 파랑색을, $+b^{*}$ 은 노랑색을 나타낸다. 측정된 $\mathrm{L}^{*}, \mathrm{a}^{*}, \mathrm{~b}^{*}$ 값을 바탕으로 실질적의 재색변화 $\left.\triangle \mathrm{E}^{*}\right)$ 는 아래의 계산식에 따라 산출하였으며 미국 표준국(National Bureau of Standards)의 색차구분에 따라 재색변화의 차이를 구분하였다.

\subsection{3 밀도 및 중량감소율 측정}

세 수종 시료를 $20 \mathrm{~mm}(\mathrm{R}) \times 20 \mathrm{~mm}(\mathrm{~T}) \times 40 \mathrm{~mm}(\mathrm{~L})$ 크기로 제작하여 열처리 온도별 밀도의 변화와 중량감소율을 측정하였다. 밀도변화와 중량감소율은 전건상태를 기준으로 다음의 식을 이용하여 계산하였으며, 10 개 시편의 평균값을 나타내었다.

\subsection{4 셀룰로오스 상대결정화도 분석}

X선회절장치(D-Max 2100V, Rigaku, Japan)를 이용하여 비열처리재와 열처리재의 셀룰로오스의 상대결정화도를 분석하였 다. 시편은 $1 \mathrm{~mm}(\mathrm{R}) \times 10 \mathrm{~mm}(\mathrm{~T}) \times 20 \mathrm{~mm}(\mathrm{~L})$ 로 제작하였으며 $40 \mathrm{kV}, 30 \mathrm{~mA}$ 조건하에서 $\mathrm{Ni}$ filter로 단색화한 $\mathrm{CuKa}$ 선을 사용하여 측정하였다. 다음의 Segal법(Segal et al., 1959)에 의해 상대결정화도를 계산하였다.

\section{3. 결과 및 고찰}

\section{1 열처리에 의한 재색변화}

Fig. 3은 세 수종의 목재시료를 각 온도에서 열처리한 사진이다. 세 수종의 목재 모두 $200^{\circ} \mathrm{C}$ 이상의 온도에서 급격하게 재색이 짙게 변화하는 것을 알 수 있다. 소나무재는 열처리에 따라 내부의 수지 성분의 용탈로 표면이 오염되는 것을 관찰할 수 있었다. 수지의 표면 오염은 $220^{\circ} \mathrm{C}$ 열처리 이후에서는 관찰할 수 없었는데 고온으로 인해 수지성분이 열분해 되어 휘발된 때문으로 판단된다.

Table 1과 Fig. 4는 열처리 온도에 따른 세 수종 목재의 재색변화를 측정한 결과를 나타낸 것이다. $\mathrm{L}^{*}$ 증가는 명도가 높아짐을 의미하고, a 증가는 붉은색으로의 변화, $b^{*}$ 증가는 노란색으로의 변화를 의미한다. 세 수종 목재 모두 열처리 온도가 높아질수록 명도 값을 나타내는 $\mathrm{L}^{*}$ 가 낮아졌는데, $200^{\circ} \mathrm{C}$ 이상에서 명도가 크게 감소하였고 육안적으로도 어두운 색을 나타냈다.

참오동나무재와 은사시나무재는 열처리 온도 증가에 따라 $\mathrm{a}^{*}, \mathrm{~b}^{*}$ 가 증가하였으나, 소나무재는 $200^{\circ} \mathrm{C}$ 이상에서 $\mathrm{b}^{*}$ 값이 감소하 는 경향을 나타냈다. 이전의 연구에서도 열처리 온도와 색변화와 관련하여 조사한 연구는 많다(Aydemir et al., 2014; Bekhta and Niemz, 2003; Brischke et al., 2007; Hidayat et al., 2015, 2016, 2017b; Yoon et al., 2008, 2009). 특히, Bekhta and $\operatorname{Niemz(2003)ㄴㅡㄴ~ㄱㅏㅁㅜㄴㅂㅣㄴㅏㅁㅜㅈㅐㅇㅢ~ㅇㅕㄹㅊㅓㄹㅣㅅㅣㄹㅎㅓㅁㅇㅔㅅㅓ~} \mathrm{L}^{*}, \mathrm{~b}^{*}$ 값이 감소하고 $\mathrm{a}^{*}$ 값이 증가하는 결과를 보고하였다. Hidayat et 
al.(2017b)의 선행연구에서 일반인을 대상으로 참오동나무재와 잣나무재의 열처리 온도별 목재 표면 재색변화의 취향을 조사한 결과, $180^{\circ} \mathrm{C} \sim 200^{\circ} \mathrm{C}$ 에서 열처리한 목재의 표면을 가장 심미적으로 아름답게 생각한다고 보고하였는데, 본 연구에 의해 그 결과를 재입증할 수 있는 것으로 생각되었다.

$\mathrm{Lab}^{*} \mathrm{ab}^{*}$ 값은 색상의 변화를 나타내며 절대적인 변화량을 나타낼 수 없지만 $\triangle \mathrm{E}^{*}$ 는 절대치를 나타내, 서로 다른 방향으로의 색변화가 일어난 두 물체의 재색 변화량도 비교할 수 있다(Han and Cho, 2005). Table 2와 Fig. 5는 열처리 온도에 따른 세 수종의 색변화량 $\left(\triangle \mathrm{E}^{*}\right)$ 을 나타낸 것이다. 세 수종의 목재 모두 $200^{\circ} \mathrm{C}$ 이상에서 급격한 $\triangle \mathrm{E}^{*}$ 값의 변화를 나타냈는데 이는 N.B.S.에 따른 색차 변화량 구분상 매우 많음(very much) 해당한다(Han and Cho, 2005). $160^{\circ} \mathrm{C}$ 열처리에 의해 참오동나무재는 미미한(slight) 변화를 나타냈지만, 은사시나무재와 소나무재는 상당한(appreciable) 변화를 나타냈다. 참오동나무재는 보다 높은 온도인 $180^{\circ} \mathrm{C}$ 에서 상당한(appreciable) 변화를 나타냈다. 따라서 참오동나무재는 다른 두 수종과 비교하여 다소 높은 온도에서 재색변화가 나타나는 것이 확인되었다. 지금까지 많은 연구자들이 열처리 온도, 시간의 증가에 따라 $\triangle \mathrm{E}^{*}$ 값의 변화를 보고하고 있다(Brischke et al., 2007; Hidayat et al., 2015, 2016, 2017b; Lim et al.,, 2014; Ra et al., 2012; Shi et al., 2011; Yoon et al., 2008, 2009). 또한 $\triangle \mathrm{E}^{*}$ 값의 증가에 따라 MOR과 MOE가 감소하고(Bekhta and Niemz, 2003; Brischke et al., 2007; Hidayat et al., 2016), 체적수축율의 증가, 밀도, 평형함수율 및 수분흡수량 감소를 보고하고 있어(Hidayat et al., 2016), 색변화와 목재의 물성 간에 깊은 관련성이 있는 것으로 생각된다.

\section{2 열처리에 의한 밀도 및 중량감소율 변화}

Table 3과 Fig. 6은 열처리에 의한 세 수종 목재의 밀도 변화와 중량감소율을 나타낸 것이다. 세 수종의 비열처리 목재의 밀도는 참오동나무재 $0.26 \mathrm{~g} / \mathrm{cm}^{3}$, 소나무 $0.50 \mathrm{~g} / \mathrm{cm}^{3}$ 및 은사시나무재 $0.55 \mathrm{~g} / \mathrm{cm}^{3}$ 였다. 열처리 온도의 증가에 따라 세 수종 목재의 밀도는 다소 감소하였으며, 세 수종의 목재 모두 $220^{\circ} \mathrm{C}$ 열처리재는 약 $10 \%$ 의 밀도의 감소를 나타냈다. 특히, 참오동나무재는 $180^{\circ} \mathrm{C}$ 열처리에서도 밀도변화가 거의 없어 열처리에 의해 비교적 안정적인 특성을 나타내는 것으로 판단되었다. 세 수종 목재의 중량감소율 또한 열처리 온도가 증가와 함께 증가하였으며 참오동나무재의 중량감소율이 가장 컸다. 특히 참오동나무재는 $180^{\circ} \mathrm{C}$ 부터 중량감소율이 상당히 컸고, 은사시나무재는 $220^{\circ} \mathrm{C}$ 에서 큰 폭으로 중량감소율이 증가하였다. 소나무재는 다른 두 수종에 비해 다소 낮은 중량 감소율을 나타냈다.

일반적으로 열처리에 의해 밀도가 감소하고 중량감소율이 높아지는 이유를 낮은 수분함량, 열처리중에 목재에 함유된 추출물 휘산, 목재 구성성분중 헤미셀룰로오스의 분해 및 분해 산물의 증발에 기인하는 것으로 알려지고 있다 (Poncsak et al. 2005; Yildiz et al. 2006; Gunduz et al., 2009; Kim, 2016). 목재에 존재하는 추출물은 목재 구성성분들에 비해 분자량이 낮은 화합물로 휘발성이 높은 물질이기 때문에 목재의 저온 $\left(120 \sim 180^{\circ} \mathrm{C}\right)$ 에서 분해는 추출물에 관련이 있는 것으로 설명하고 있다 (Shebani et al. 2008; Kim, 2016). 헤미셀룰로오스는 $180^{\circ} \mathrm{C}$ 이상에서 열분해 되는데(Liang and Wang, 2017), 친수성이 큰 헤미셀룰로오스가 감소되어 흡습성이 낮아져서 이에 따라 치수안정성이 증가하게 된다(Korkut et al., 2008). 따라서 헤미셀룰로 오스의 함량이 높은 수종은 $180^{\circ} \mathrm{C}$ 이상의 열처리 과정 중 높은 중량 감소율을 나타내는 것으로 생각된다.

Chong and Park(2008)의 연구결과에 의하면 참오동나무재의 헤미셀룰로오스 함량은 $17.8 \%$, 소나무재 $12.9 \%$, 은사시나무재 $26.9 \%$ 로 보고하였으며, 온수에 의한 추출물 함량은 참오동나무재 $8.8 \%$, 소나무재 $1.6 \%$, 은사시나무재 $3.6 \%$ 를 함유하고 있다고 보고하였다. 따라서 본 연구에서 참오동나무가 다른 수종에 비해 열처리에 의해 낮은 밀도변화와 높은 중량감소율을 보인 이유는 추출물, 헤미셀룰로오스 등의 화학성분의 함량 및 특성차이에 기인하는 것으로 생각된다.

\section{3 상대결정화도}

Fig. 7은 세 수종 목재의 열처리 목재를 측정한 X선회절 강도곡선이다. 세 수종의 목재 모두 열처리에 의해 셀룰로오스 결정의 주요 면인 (1-10), (110) 및 (200)의 강도가 증가하는 것이 확인되었다. Table 4는 열처리 전·후의 세 수종 목재의 X선회절 강도곡선으로부터 계산한 상대결정화도의 결과이다. 비열처리 목재시료에서는 참오동나무재가 가장 낮은 상대결정화도를 나타 냈고, 은사시나무재가 가장 높은 값을 나타냈다. 세 수종의 목재 모두 열처리 온도의 증가와 함께 상대결정화도가 다소 증가하는 경향을 나타냈다. 특히, 오동나무재의 열처리재가 비열처리재의 상대결정화도에 비해 가장 큰 상대결정화도의 증가를 나타내는 특성을 보여주었다.

Bhuiyan et al. (2000)에 의하면 $180-220^{\circ} \mathrm{C}$ 에서 목재셀룰로오스를 열처리하였을 때 열처리초기단계에서는 상대결정화도가 증가한다고 보고하였고, Hidayat et al.(2016)은 열처리에 의해 셀룰로오스의 상대결정화도는 다소 증가되며 처리시간이 두 시간 이상 지속되면 감소하는 경향이 있다고 보고하였다. 또한 Kubojima et al.(1998)과 Kocaefe et al.(2008)은 단시간의 
Yun Ki, Kim • Gu Joong Kwon • Ah Ran Kim • Hee Soo Lee • Byantaradarsan Purusatama •

Seung Hwan Lee $\cdot$ Chun Won Kang $\cdot$ Nam Hun Kim

열처리에 의해 셀룰로오스의 상대결정화도가 증가하고 역학적 성질의 변화에도 영향을 주는 것으로 보고하고 있다.

이상과 같이 본 연구에서 열처리에 의해 상대결정화도가 다소 증가되는 것이 재확인되었는데, 상대결정화도는 평형함수율

(Dwiant et al., 1997; Kubojima et al., 1998; Ishiguri et al., 2003)과 MOE(Hirai et al., 1972; Inoue and Norimoto, 1991;

Ishiguri et al., 2003) 등 목재의 물성에 영향을 주는 중요 인자이므로 온도, 시간, 수종 등과 관련한 검토가 더욱 필요한 것으로 생각된다.

\section{4. 결 론}

참오동나무재의 열처리 특성을 은사시나무, 소나무와 비교, 조사한 결과는 다음과 같다.

참오동나무재, 은사시나무재 및 소나무재의 명도( $\left.\mathrm{L}^{*}\right)$ 는 열처리온도와 함께 감소하였고, 적-녹색도( $\left.\mathrm{a}^{*}\right)$ 와 황-청색도( $\left.\mathrm{b}^{*}\right)$ 는 열처리 온도 증가에도 거의 변화가 없었으나 소나무재의 황-청색도 $\left(\mathrm{b}^{*}\right)$ 는 $200^{\circ} \mathrm{C}$ 이상에서 뚜렷하게 감소하였다. 재색변화 $\left(\Delta \mathrm{E}^{*}\right)$ 는 참오동나무재는 $180^{\circ} \mathrm{C}$ 부터, 은사시나무와 소나무재는 $160^{\circ} \mathrm{C}$ 부터 다소 크게 증가하였다. 세 수종의 목재 모두 $200^{\circ} \mathrm{C}$ 이상에 서 $\Delta \mathrm{E}^{*}$ 가 뚜렷하게 증가하였고, $220^{\circ} \mathrm{C}$ 에서 세 수종 목재가 비슷한 $\Delta \mathrm{E}^{*}$ 를 나타냈다.

공시수종 목재의 밀도는 $220^{\circ} \mathrm{C}$ 의 열처리에 의해 약 $10 \%$ 감소되었으며, $160 \sim 180^{\circ} \mathrm{C}$ 의 열처리에서 참오동나무재의 밀도 변화는 없었다. 중량감소율은 참오동나무재가 가장 컸으며, 특히 $180^{\circ} \mathrm{C}$ 이상에서 참오동나무재의 중량이 크게 감소하였다.

공시수종의 목재 모두 열처리 온도의 증가와 함께 상대결정화도가 다소 증가하는 경향을 나타냈는데, 오동나무재는 비열처리 재와 비교하여 가장 큰 상대결정화도의 증가를 나타냈다.

이상의 연구결과, 참오동나무, 은사시나무 및 소나무재의 열처리과정 중 재색, 밀도, 상대결정화도의 변화를 확인하였고, 이러한 특성 변화에 관한 자료는 실용적인 측면에서 목재산업에 새로운 소재로의 활용에 기초자료로 제공될 수 있을 것으로 생각되었다. 